\title{
Anticancer effects of $\beta$-elemene with hyperthermia in lung cancer cells
}

\author{
ZHIBING WU ${ }^{1-3^{*}}$, TING WANG ${ }^{4 *}$, YANMEI ZHANG ${ }^{5}$, ZHISHUANG ZHENG $^{1}$, SHUHUAN YU $^{1}$, \\ SAISAI JING ${ }^{1,3}$, SUMEI CHEN ${ }^{1,3}$, HAO JIANG $^{6}$ and SHENGLIN MA ${ }^{1,3}$
}

${ }^{1}$ Center of Hyperthermia Oncology, Hangzhou First People's Hospital, Hangzhou, Zhejiang 310006; ${ }^{2}$ Department of Radiation Oncology, Hangzhou Cancer Hospital, Hangzhou, Zhejiang 310002; ${ }^{3}$ Key Laboratory of Molecular Oncology of Chinese Medicine and Western Medicine, Hangzhou First People's Hospital, Hangzhou, Zhejiang 310006;

${ }^{4}$ Department of Oncology, Yiwu Central Hospital, Yiwu, Zhejiang 322000; ${ }^{5}$ Zhejiang Academy of Medical Sciences, Hangzhou, Zhejiang 310005; ${ }^{6}$ Department of Oncology, Zhejiang Hospital, Hangzhou, Zhejiang 310013, P.R. China

Received September 24, 2015; Accepted January 26, 2017

DOI: $10.3892 / \mathrm{etm} .2017 .4350$

\begin{abstract}
. $\beta$-elemene is a novel, plant-derived anticancer drug, which has been used to target multiple solid tumor types. Hyperthermia is an adjuvant therapeutic modality to treat cancer. However, the underlying mechanisms associated with the efficacy of these two treatments are largely unknown. The aim of the present study was to evaluate the effects of $\beta$-elemene combined with hyperthermia in lung cancer cell lines. An MTT assay was used to determine cell viability. The cell cycle and apoptosis were analyzed using flow cytometry. The morphology of cells during apoptosis was determined using a transmission electron microscope. The expression levels of P21, survivin, caspase-9, B-cell lymphoma 2 (Bcl-2) and Bcl-2-like protein 4 (Bax) mRNA were detected using quantitative polymerase chain reaction. $\beta$-elemene with hyperthermia treatment significantly inhibited the viability and increased the apoptosis rate of A549 cells compared with $\beta$-elemene treatment alone $(\mathrm{P}<0.01)$, and significantly decreased the proportion of cells in $\mathrm{S}$ phase compared with the control $(\mathrm{P}<0.01)$. Morphological observation using transmission electron microscopy indicated cross-sectional features of apoptosis: Chromatin condensation, reduced integrity of the plasma membrane, increased cellular granularity, nuclear collapse and the formation of apoptotic bodies. $\beta$-elemene with hyperthermia treatment significantly promoted P21 and Bax mRNA expression $(\mathrm{P}<0.01)$ and significantly decreased caspase-9, Bcl-2 and survivin mRNA expression $(\mathrm{P}<0.01)$ in
\end{abstract}

Correspondence to: Dr Zhibing Wu, Center of Hyperthermia Oncology, Hangzhou First People's Hospital, 261 Huansha Road, Hangzhou, Zhejiang 310006, P.R. China

E-mail:wu_zhibing@163.com

${ }^{*}$ Contributed equally

Key words: hyperthermia, $\beta$-elemene, non-small cell lung cancer, apoptosis, cell cycle
A549 cells. In conclusion, $\beta$-elemene with hyperthermia has a significant inhibitory effect on A549 cells. This occurs through reducing $\mathrm{S}$ phase and inducing apoptosis, via an increase in P21 and Bax expression and a decrease in caspase-9, Bcl-2 and survivin expression.

\section{Introduction}

Lung cancer is the leading cause of cancer-related mortality throughout the world. Non-small cell lung cancer (NSCLC) in particular has low survival rates and poor outcomes (1). The optimal chemotherapeutic treatments for NSCLC are often limited by dose-related toxicity (2). Developing new treatments is necessary in order to improve the prognosis for NSCLC patients. Traditional Chinese Medicine is believed by some to be beneficial in anticancer treatment and in reducing the side effects of conventional treatment (3-9).

$\beta$-elemene (1-methyl-1-vinyl-2,4-di-isopropenyl-cyclohexane) is a novel anticancer drug extracted from the ginger plant, Curcuma zedoaria. It has been used to target multiple types of solid tumor, including lung, esophageal and breast cancers, hepatocarcinoma, glioblastoma and melanoma. $\beta$-elemene has been reported to inhibit the growth and DNA synthesis of multiple types of tumor cell, resulting in the apoptosis or suppressed growth of tumors, without severe side effects (10-17). Hyperthermia is an adjuvant therapeutic modality in cancer treatment, by which the tumor region is maintained at high temperatures in order to inhibit the growth of cancer cells. It can cause regression of multiple cancer types, including lung, breast, colon and pancreatic cancer (18-21). In addition, hyperthermia causes cancer cells to become more sensitive to the effects of radiation and certain anticancer drugs (22-25). The mechanisms of hyperthermia in treating cancers may be related to inhibiting DNA repair, promoting intracellular accumulation of chemical agents, altering cellular $\mathrm{Ca}^{2+}$ homeostasis, inducing cell cycle arrest and apoptosis, increasing membrane permeability and rearranging the cytoskeleton (26-28). Hyperthermia also has direct cytotoxic effects, which provide a number of other clinical advantages, including 
activation of the immune system against tumors, improvement of oxygenation and enhancing drug delivery (29-32). However, the underlying mechanisms associated with its efficacy are largely unknown.

The current study aimed to investigate the efficacy of $\beta$-elemene combined with hyperthermia treatment in suppressing lung cancer cell growth. The role of $\beta$-elemene and hyperthermia in inhibiting NSCLC cell growth was investigated and cell cycle arrest, apoptosis rates and the expression of key genes were evaluated. The results of the current study could provide a theoretical basis for their use in a novel anticancer therapeutic modality.

\section{Materials and methods}

Chemicals and reagents. $\beta$-elemene was obtained from Dalian Holley Kingkong Pharmaceutical Co., Ltd. (cat. no. 081152; Dalian, China). Dulbecco's modified Eagle's medium (DMEM) and fetal calf serum were obtained from HyClone (GE Healthcare Life Sciences, Logan, UT, USA). Cycletest ${ }^{\mathrm{TM}}$ Plus DNA Reagent kit and Annexin V-Fluorescein Isothiocyanate and Propidium Iodide (PI) Apoptosis Detection kits were purchased from BD Biosciences (Franklin Lakes, NJ, USA). All other chemical reagents were purchased from Sigma-Aldrich (Merck KGaA, Darmstadt, Germany).

Cell lines and culture. The NSCLC cell line A549 was purchased from the Cell Bank of Type Culture Collection of Chinese Academy of Sciences (Shanghai, China) and cultured in DMEM supplemented with $10 \%$ fetal calf serum, in a humidified incubator (Thermo Fischer Scientific, Inc., Waltham, MA, USA) containing $5 \% \mathrm{CO}_{2}$ at $37^{\circ} \mathrm{C}$.

MTT assay. Cells were seeded in 96-well plates at 8,000 cells/well and cultured overnight at $37^{\circ} \mathrm{C}$. Various concentrations of $\beta$-elemene $(0,15,30,60,125,250$ and $500 \mu \mathrm{g} / \mathrm{ml})$ were added and the plates were incubated at different temperatures $\left(37\right.$ and $42^{\circ} \mathrm{C}$ ) for $1.5 \mathrm{~h}$ in a humidified atmosphere containing 5\% $\mathrm{CO}_{2}$. After $24 \mathrm{~h}, 5 \mathrm{mg} / \mathrm{ml}$ MTT was added to each well for $4 \mathrm{~h}$. Then, the level of formazan was assessed by measuring the absorbance using a Tecan microplate reader (Tecan Group Ltd., Männedorf, Switzerland) at $490 \mathrm{~nm}$.

Cell cycle and apoptosis assay. The experimental groups were as follows: $15 \mu \mathrm{g} / \mathrm{ml} \beta$-elemene; $60 \mu \mathrm{g} / \mathrm{ml} \beta$-elemene; hyperthermia; hyperthermia and $15 \mu \mathrm{g} / \mathrm{ml} \beta$-elemene; and hyperthermia and $60 \mu \mathrm{g} / \mathrm{ml} \beta$-elemene. Hyperthermia groups were incubated at $42^{\circ} \mathrm{C}$ for $1.5 \mathrm{~h}$. Cells were treated with or without $\beta$-elemene and/or hyperthermia according to their experimental group at $37^{\circ} \mathrm{C}$ for $24 \mathrm{~h}$. The control group received neither $\beta$-elemene nor hyperthermia. Then the cells were harvested and incubated in $10 \mu \mathrm{g} / \mathrm{ml} \mathrm{RNase}$ for $30 \mathrm{~min}$ at $37^{\circ} \mathrm{C}$ and stained with $50 \mu \mathrm{g} / \mathrm{ml}$ PI for $1 \mathrm{~h}$ at $4^{\circ} \mathrm{C}$ in the dark. Cell cycle analysis was performed on a fluorescence-activated cell sorting Calibur flow cytometer (BD Biosciences). Cells were resuspended in DMEM, then stained with PI and Annexin V. The flow cytometer was used to analyze the samples for apoptosis.
Morphology of apoptotic cells. Cells were collected and fixed with $2.5 \%$ glutaraldehyde in $0.02 \mathrm{M}$ phosphate-buffered saline (pH 7.4) at $4^{\circ} \mathrm{C}$ for $4 \mathrm{~h}$ and post-fixed in $1 \%$ osmic acid for $1 \mathrm{~h}$, dehydrated in an ascending acetone series and subsequently embedded in epoxy resin (Sigma-Aldrich; Merck KGaA) at $62^{\circ} \mathrm{C}$ for $48 \mathrm{~h}$. Ultrathin $70-\mathrm{nm}$ sections were stained with uranyl acetate and lead citrate. The ultrastructural organization was observed using a JEM-1200EX transmission electron microscope (JEOL, Ltd., Tokyo, Japan).

Reverse transcription-quantitative polymerase chain reaction (RT-qPCR). Cells were cultured in 6-cm culture capsules and treated according to the aforementioned group conditions for $24 \mathrm{~h}$. The ABI 7500 Real Time PCR System (Applied Biosystems; Thermo Fisher Scientific, Inc.) was used for RT-qPCR assays. Total RNA was extracted from A549 cells using TRIzol reagent (Invitrogen; Thermo Fisher Scientific, Inc.). P21, survivin, caspase-9, B-cell lymphoma 2 (Bcl-2) and Bcl-2-like protein 4 (Bax) mRNA levels were measured using an SYBR PrimeScript RT-PCR Kit (Takara Bio, Inc., Otsu, Japan).

Statistical analysis. All experiments were performed in triplicate. Data are presented as the mean \pm standard error of the mean. Differences among treatment groups were analyzed using the Student's t-test and SPSS 17.0 software (SPSS, Inc., Chicago, IL, USA). $\mathrm{P}<0.05$ was considered to indicate a statistically significant difference.

\section{Results}

$\beta$-elemene with hyperthermia inhibits proliferation of A549 cells. $\beta$-elemene inhibited the growth of A549 cells in a dose-dependent manner, and the half maximal inhibitory concentration $\left(\mathrm{IC}_{50}\right)$ was $35.43 \mu \mathrm{g} / \mathrm{ml}$. $\beta$-elemene $(500 \mu \mathrm{g} / \mathrm{ml})$ with hyperthermia significantly increased the inhibition of A549 cells compared with $\beta$-elemene $(500 \mu \mathrm{g} / \mathrm{ml})$ treatment alone $(\mathrm{P}<0.01$; Fig. 1).

$\beta$-elemene with hyperthermia decreases $S$ phase of A549 cells. Flow cytometric analysis revealed the effect of $\beta$-elemene with or without hyperthermia on cell cycle distribution. Treatment with hyperthermia significantly decreased the percentage of cells in $S$ phase at all concentrations of $\beta$-elemene $(\mathrm{P}<0.01$; Fig. 2). The percentage of cells at $S$ phase after $\beta$-elemene $(60 \mu \mathrm{g} / \mathrm{ml})$ treatment and hyperthermia decreased from 35.60 to $30.75 \%$ compared with the control group. Hyperthermia treatment without $\beta$-elemene resulted in a significant reduction in $\mathrm{S}$ phase cells $(\mathrm{P}<0.01)$, but treatment with hyperthermia and $\beta$-elemene does not appear to have had a significant effect compared with $\beta$-elemene alone (Fig. 2).

$\beta$-elemene with hyperthermia induces apoptosis in A549 cells. $\beta$-elemene treatment was found to increase the rate of apoptosis in A549 cells ( $\mathrm{P}<0.01$; Fig. 3). Hyperthermia treatment also significantly increased the rate of apoptosis in A549 cells compared with the control $(0 \mu \mathrm{g} / \mathrm{ml} \beta$-elemene $)$ or with $\beta$-elemene treatment alone (15 or $60 \mu \mathrm{g} / \mathrm{ml})($ all $\mathrm{P}<0.01$; Fig. 3 ).

Furthermore, morphological observation of $\beta$-elemene with hyperthermia-induced apoptosis in A549 cells using 


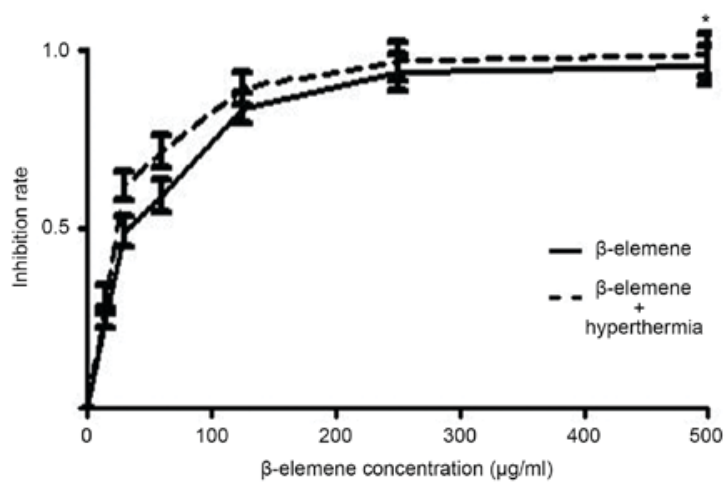

Figure 1. Inhibition rates of $\beta$-elemene with or without hyperthermia in A549 cells. Percentage of cell viability was determined using an MTT assay. ${ }^{*} \mathrm{P}<0.01$ vs. corresponding $\beta$-elemene treatment without hyperthermia.

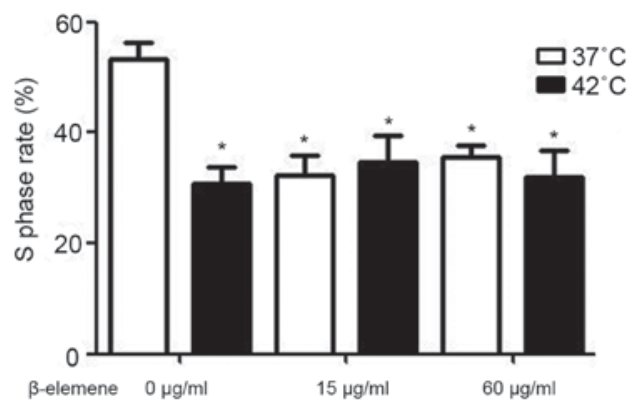

Figure 2. Cell cycle distribution induced by $\beta$-elemene with or without hyperthermia. The percentage of cells in $\mathrm{S}$ phase in different treatment groups was evaluated by flow cytometry. ${ }^{*} \mathrm{P}<0.01$ vs. control group $\left(37^{\circ} \mathrm{C}, 0 \mu \mathrm{g} / \mathrm{ml}\right.$ $\beta$-elemene).

transmission electron microscopy showed cross-sectional features of apoptosis. Hyperthermia and $\beta$-elemene treatment showed increased levels of chromatin condensation, nuclear collapse and apoptotic body formation compared with the control group or $\beta$-elemene treatment alone (Fig. 4).

$\beta$-elemene promotes $P 21$ and Bax expression and suppresses caspase-9, Bcl-2 and survivin expression in A549 cells. RT-qPCR was used to identify the expression of P21, survivin, caspase-9, Bax and Bcl-2 genes. The results indicated a significant increase in P21 and Bax mRNA expression in the $\beta$-elemene $(60 \mu \mathrm{g} / \mathrm{ml})$ and hyperthermia treatment group compared with the $\beta$-elemene and control groups $(\mathrm{P}<0.01$; Fig. 5). Furthermore, a significant decrease in caspase-9, Bcl-2 and survivin mRNA expression was observed in the $\beta$-elemene $(60 \mu \mathrm{g} / \mathrm{ml})$ with hyperthermia group compared with the $\beta$-elemene and control groups $(\mathrm{P}<0.01)$. These data suggested that $\beta$-elemene triggered apoptosis in vitro through an apoptosis pathway related to the aforementioned genes.

\section{Discussion}

The antitumor effect of $\beta$-elemene has been demonstrated in multiple types of tumor, particularly in lung cancer treatment, but the underlying mechanism remains unclear (10-17). Hyperthermia can be a highly effective cancer treatment, particularly when combined with chemotherapy, radiotherapy

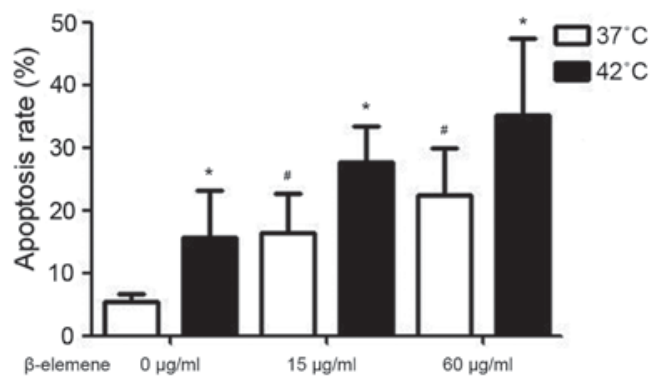

Figure 3. Apoptosis induced by $\beta$-elemene with or without hyperthermia. The percentage of apoptotic cells in different treatment groups was evaluated by flow cytometry. ${ }^{\prime \prime} \mathrm{P}<0.01$ vs. control group $\left(37^{\circ} \mathrm{C}, 0 \mu \mathrm{g} / \mathrm{ml} \beta\right.$-elemene), "P $<0.01$ vs. corresponding $\beta$-elemene treatment without hyperthermia.
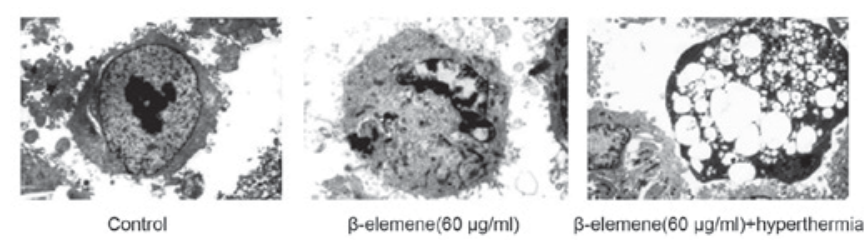

Figure 4. Transmission electron microscopy of cell groups. Higher levels of cell shrinkage, chromatin condensation, nuclear collapse and apoptotic bodies are visible in the $60 \mu \mathrm{g} / \mathrm{ml} \beta$-elemene group and $60 \mu \mathrm{g} / \mathrm{ml}$ $\beta$-elemene + hyperthermia group compared with the control group.

or immunotherapy $(33,34)$. Hyperthermia can inhibit DNA repair, promote intracellular accumulation of chemical agents, increase membrane permeability, alter cellular $\mathrm{Ca}^{2+}$ homeostasis, induce cell cycle arrest and apoptosis, and rearrange the cytoskeleton $(25,27,28,30)$. Hyperthemia treatment has previously been found to affect various cellular targets, including DNA, proteins, membranes and the cytoskeleton, of carcinoma cells (35).

The present study investigated whether combining $\beta$-elemene treatment with hyperthermia could improve its antitumor activity. It was found that $\beta$-elemene with hyperthermia could inhibited the growth of A549 cells significantly more than $\beta$-elemene treatment alone. Furthermore, it was shown in the present study that $\beta$-elemene with hyperthermia altered the cell cycle distribution, significantly decreasing the percentage of cells in S phase compared with the control. Cell cycle regulation serves a key function in cell proliferation, and P21 is considered to be a key cell cycle checkpoint protein $(36,37)$. In the present study, it was demonstrated that $\beta$-elemene with hyperthermia significantly increased the expression of P21, which resulted in a decreased S phase in the A549 cells. This suggests that $\mathrm{P} 21$ mediates cell proliferation via decreasing $\mathrm{S}$ phase in lung cancer cells.

Caspase-3 is a key executor in apoptosis and therefore serves a crucial function in programmed cell death. Apoptosis is related to the activation of Bax, which then binds to Bak to induce the release of cytochrome $\mathrm{C}$. The release of cytochrome $\mathrm{C}$ is related to the cleavage of caspase-9. Interaction between caspase- 9 and caspase- $3,-6$ and -7 activates the latter caspases in cells. Finally, activated caspase- 3 causes DNA breakage and induces cell apoptosis (38-40). In this study, $\beta$-elemene with hyperthermia decreased caspase- 9 expression and increased Bax expression. It is proposed that $\beta$-elemene 


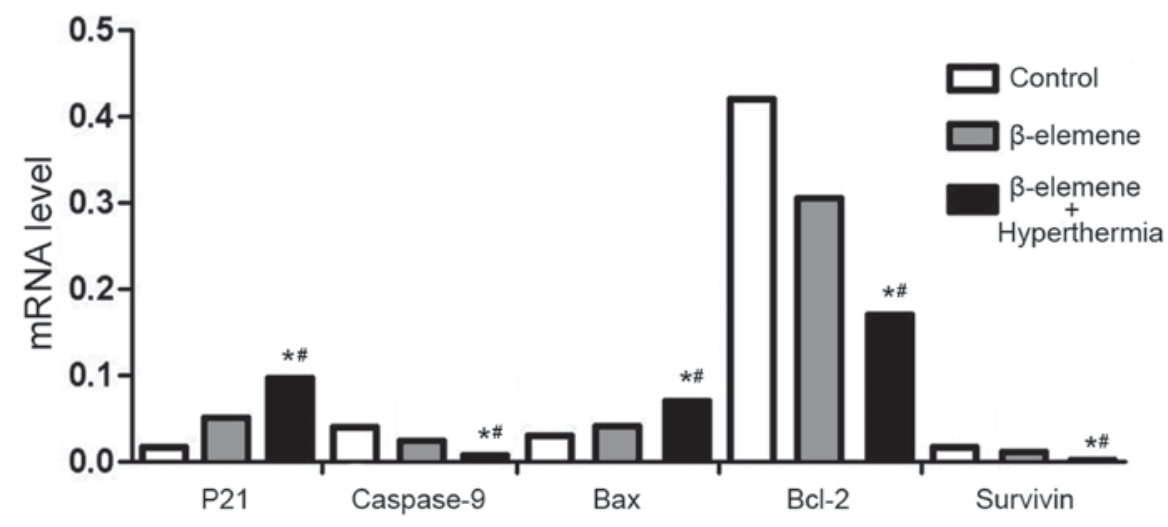

Figure 5. The mRNA levels of P21, Bcl-2, Bax, caspase-9 and survivin following $\beta$-elemene $(60 \mu \mathrm{g} / \mathrm{ml})$ treatment with hyperthermia. "P<0.01 vs. control, ${ }^{\text {"}} \mathrm{P}<0.01$ vs. $\beta$-elemene. Bcl-2, B-cell lymphoma 2 ; Bax, Bcl-2-like protein 4.

with hyperthermia decreased caspase-9 activation through the induction of Bax expression. This suggests that $\beta$-elemene and hyperthermia-induced apoptosis involves a caspase-dependent pathway.

Bcl-2 can maintain cell survival by limiting the pro-apoptotic effects of Bax and suppressing the release of cytochrome $\mathrm{C}$ from mitochondria $(41,42)$. Therefore, the $\mathrm{Bcl}-2 / \mathrm{Bax}$ ratio can induce the apoptosis of cells. It has been indicated that the $\mathrm{Bcl}-2 / \mathrm{Bax}$ ratio may be more critical in determining apoptosis than either protein alone $(43,44)$. Furthermore, certain Bcl-2 family proteins have previously been found to be modulated in apoptosis progression. The balance between pro- and anti-apoptotic members of the Bcl-2 family proteins decides the fate of the cell, and an increased proportion of pro-apoptotic proteins results in apoptotic cell death $(45,46)$. In the present study, $\beta$-elemene with hyperthermia induced apoptosis in A549 cells, and also increased Bax expression and decreased Bcl-2 expression. These findings suggest that Bcl-2 family proteins play a critical role in $\beta$-elemene and hyperthermia-induced cell death in lung cancer cells.

Survivin is a member of the inhibitor of apoptosis family. It is expressed in $\sim 60$ different human tumor types, with the highest levels of expression observed in breast and lung cancer cell lines (47-49). The survivin protein inhibits caspase activation, thereby leading to negative regulation of apoptosis. This has been demonstrated by the disruption of survivin induction pathways leading to an increase in apoptosis and a decrease in tumor growth $(50,51)$. Survivin inhibits both Bax and Fas-induced apoptotic pathways and blocks apoptosis by directly inhibiting caspases (52). Consistent with this, in the present study, $\beta$-elemene with hyperthermia was found to both suppress the expression of survivin and induce apoptosis.

In conclusion, $\beta$-elemene with hyperthermia was shown to have a significant inhibitory effect in A549 cells. This occurs through decreasing $\mathrm{S}$ phase and inducing apoptosis, with a simultaneous increase in P21 and Bax mRNA expression and a decrease in caspase-9, Bcl-2 and survivin mRNA expression. The present study was a preliminary exploration into the anticancer effects of $\beta$-elemene with hyperthermia in lung cancer cells. Further research into the effects $\beta$-elemene and hyperthermia treatment would be valuable in improving therapeutic strategies for lung cancer.

\section{Acknowledgements}

The present study was supported by a grant from the Zhejiang Traditional Medicine Project (grant no. 2013ZA106).

\section{References}

1. Siegel RL, Miller KD and Jemal A: Cancer statistics, 2017. CA Cancer J Clin 67: 7-30, 2017.

2. Schiller JH, Harrington D, Belani CP, Langer C, Sandler A, Krook J, Zhu J and Johnson DH; Eastern Cooperative Oncology Group: Comparison of four chemotherapy regimens for advanced non-small-cell lung cancer. N Engl J Med 346: 92-98, 2002.

3. Jiang H, Zhao PJ, Su D, Feng J and Ma SL: Paris saponin I induces apoptosis via increasing the $\mathrm{Bax} / \mathrm{Bcl}-2$ ratio and caspase-3 expression in gefitinib-resistant non-small cell lung cancer in vitro and in vivo. Mol Med Rep 9: 2265-2272, 2014

4. Zhao P, Jiang H, Su D, Feng J, Ma S and Zhu X: Inhibition of cell proliferation by mild hyperthermia at $43 \mathrm{C}$ with paris saponin I in the lung adenocarcinoma cell line PC-9. Mol Med Rep 11: 327-332, 2015.

5. Jiang H, Zhao P, Feng J, Su D and Ma S: Effect of paris saponin I on radiosensitivity in a gefitinib-resistant lung adenocarcinoma cell line. Oncol Lett 7: 2059-2064, 2014.

6. Song S, Du L, Jiang H, Zhu X, Li J and Xu J: Paris saponin I sensitizes gastric cancer cell lines to cisplatin via cell cycle arrest and apoptosis. Med Sci Monit 22: 3798-3803, 2016.

7. Zhao PJ, Song SC, Du LW, Zhou GH, Ma SL, Li JH, Feng JG, Zhu XH and Jiang H: Paris saponins enhance radiosensitivity in a gefitinib-resistant lung adenocarcinoma cell line by inducing apoptosis and G2/M cell cycle phase arrest. Mol Med Rep 13: 2878-2884, 2016.

8. Zhu X, Jiang H, Li J, Xu J and Fei Z: Anticancer effects of paris saponins by apoptosis and PI3K/AKT pathway in gefitinib-resistant non-small cell lung cancer. Med Sci Monit 22: 1435-1441, 2016.

9. Zheng R, Rao Y, Jiang H, Liu X, Zhu X,Li J and Xu J: Therapeutic potential of ginsenoside Rg3 via inhibiting Notch/HES1 pathway in lung cancer cells. Transl Cancer Res 5: 464-469, 2016.

10. Gong M, Liu Y, Zhang J, Gao YJ, Zhai PP, Su X, Li X, Li Y, Hou L and Cui $\mathrm{XN}$ : $\beta$-Elemene inhibits cell proliferation by regulating the expression and activity of topoisomerases I and II $\alpha$ in human hepatocarcinoma HepG-2 cells. Biomed Res Int 2015: 153987, 2015.

11. Liu S, Zhou L, Zhao Y and Yuan Y: $\beta$-elemene enhances both radiosensitivity and chemosensitivity of glioblastoma cells through the inhibition of the ATM signaling pathway. Oncol Rep 34: 943-951, 2015.

12. Dong Y, Li L, Wang L, Zhou T, Liu JW and Gao YJ: Preliminary study of the effects of $\beta$-elemene on MCF-7/ADM breast cancer stem cells. Genet Mol Res 14: 2347-2355, 2015.

13. Hu Z, Wu H, Li Y, Hou Q, Wang Y, Li S, Xia B and Wu S: $\beta$-Elemene inhibits the proliferation of esophageal squamous cell carcinoma by regulating long noncoding RNA-mediated inhibition of hTERT expression. Anticancer Drugs 26: 531-539, 2015. 
14. Li G, Xie B, Li X, Chen Y, Xu Y, Xu-Welliver M and Zou L: Downregulation of peroxiredoxin-1 by $\beta$-elemene enhances the radiosensitivity of lung adenocarcinoma xenografts. Oncol Rep 33: 1427-1433, 2015.

15. Zhao S, Wu J, Zheng F, Tang Q, Yang L, Li L, Wu W and Hann SS: $\beta$-elemene inhibited expression of DNA methyltransferase 1 through activation of ERK1/2 and AMPK $\alpha$ signalling pathways in human lung cancer cells: The role of Spl. J Cell Mol Med 19: 630-641, 2015.

16. Zhang J, Zhang Hd, Chen L, Sun DW, Mao Cf, Chen W, Wu JZ, Zhong SL, Zhao JH and Tang JH: $\beta$-elemene reverses chemoresistance of breast cancer via regulating MDR-related microRNA expression. Cell Physiol Biochem 34: 2027-2037, 2014.

17. Shi H, Liu L, Liu LM, Geng J and Chen L: Inhibition of tumor growth by $\beta$-elemene through downregulation of the expression of uPA, uPAR, MMP-2 and MMP-9 in a murine intraocular melanoma model. Melanoma Res 25: 15-21, 2015.

18. Arriortua OK, Garaio E, Herrero de la Parte B, Insausti M, Lezama L, Plazaola F, García JA, Aizpurua JM, Sagartzazu M, Irazola $\mathrm{M}$, et al: Antitumor magnetic hyperthermia induced by RGD-functionalized $\mathrm{Fe} 3 \mathrm{O} 4$ nanoparticles, in an experimental model of colorectal liver metastases. Beilstein J Nanotechnol 7: $1532-1542,2016$

19. Wu SK, Chiang CF, Hsu YH, Liou HC, Fu WM and Lin WL: Pulsed-wave low-dose ultrasound hyperthermia selectively enhances nanodrug delivery and improves antitumor efficacy for brain metastasis of breast cancer. Ultrason Sonochem 36 : 198-205, 2017.

20. Bai Z, Shi Y, Wang J, Qiu L, Monroe EJ, Teng G, Zhang F and Yang X: Intratumoral radiofrequency hyperthermia-enhanced direct chemotherapy of pancreatic cancer. Oncotarget 8: 3591-3599, 2017

21. Wan $\mathrm{J}$ and $\mathrm{Wu} \mathrm{W}$ : Hyperthermia induced HIF-1a expression of lung cancer through AKT and ERK signaling pathways. J Exp Clin Cancer Res 35: 119, 2016.

22. van der Zee J, González González D, van Rhoon GC, van Dijk JD, van Putten WL and Hart AA: Comparison of radiotherapy alone with radiotherapy plus hyperthermia in locally advanced pelvic tumours: A prospective, randomised, multicentre trial. Dutch deep hyperthermia group. Lancet 355: 1119-1125, 2000

23. Jones EL, Samulski TV, Dewhirst MW, Alvarez-Secord A Berchuck A, Clarke Pearson D, Havrilesky LJ, Soper J and Prosnitz LR: A pilot phase II trial of concurrent radiotherapy, chemotherapy and hyperthermia for locally advanced cervical carcinoma. Cancer 98: 277-282,2003.

24. Sakurai H, Kitamoto Y, Saitoh J, Nonaka T, Ishikawa H, Kiyohara H, Shioya M, Fukushima M, Akimoto T, Hasegawa M and Nakano T: Attenuation of chronic thermotolerance by KNK437, a benzylidene lactam compound, enhances thermal radiosensitization in mild temperature hyperthermia combined with low dose-rate irradiation. Int J Radiat Biol 81: 711-718, 2005.

25. Han SI, Duong HQ, Choi JE, Lee TB, Kim CH, Lee SY, Jeon HM, Shin SH, Lim SC and Kang HS: Hyperthermia switches glucose depletion-induced necrosis to apoptosis in A549 lung adenocarcinoma cells. Int J Oncol 32: 851-860, 2008.

26. Coss RA and Linnemans WA: The effects of hyperthermia on the cytoskeleton: A review. Int J Hyperthermia 12: 173-196, 1996.

27. Wachsberger PR and Iliakis G: Hyperthermia does not affect rejoining of DNA double-strand breaks in a cell-free assay. Int J Radiat Biol 76: 313-326, 2000

28. Luchetti F, Mannello F, Canonico B, Battistelli M, Burattini S, Falcieri E and Papa S: Integrin and cytoskeleton behaviour in human neuroblastoma cells during hyperthermia-related apoptosis. Apoptosis 9: 635-648, 2004.

29. Song CW, Shakil A, Osborn JL and Iwata K: Tumour oxygenation is increased by hyperthermia at mild temperatures. Int J Hyperthermia 12: 367-373, 1996.

30. Kong G, Anyarambhatla G, Petros WP, Braun RD, Colvin OM Needham D and Dewhirst MW: Efficacy of liposomes and hyperthermia in a human tumor xenograft model: Importance of triggered drug release. Cancer Res 60: 6950-6957, 2000.

31. Milani V, Noessner E, Ghose S, Kuppner M, Ahrens B, Scharner A, Gastpar R and Issels RD: Heat shock protein 70: Role in antigen presentation and immune stimulation. Int Hyperthermia 18: 563-575, 2002.

32. Zhao P, Jiang H, Su D, Feng J, Ma S and Zhu X: Inhibition of cell proliferation by mild hyperthermia at $43^{\circ} \mathrm{C}$ with paris saponin I in the lung adenocarcinoma cell line PC-9. Mol Med Rep 11: $327-332,2015$
33. Wust P, Hildebrandt B, Sreenivasa G, Rau B, Gellermann J, Riess H, Felix R and Schlag PM: Hyperthermia in combined treatment of cancer. Lancet Oncol 3: 487-497, 2002

34. Saga T, Sakahara H, Nakamoto Y, Sato N, Ishimori T, Mamede M, Kobayashi H, Masunaga S, Sasai K, Kuroki M and Konishi J: Enhancement of the therapeutic outcome of radio-immunotherapy by combination with whole-body mild hyperthermia. Eur J Cancer 37: 1429-1434, 2001.

35. Speit G and Schütz P: Hyperthermia-induced genotoxic effects in human A549 cells. Mutat Res: 747-748: 1-5, 2013.

36. Bizarro A, Ferreira IC, Soković M, van Griensven LJ, Sousa D, Vasconcelos MH and Lima RT: Cordyceps militaris (L.) link fruiting body reduces the growth of a non-small cell lung cancer cell line by increasing cellular levels of p53 and p21. Molecules 20: 13927-13940, 2015.

37. Sikdar S, Mukherjee A and Khuda-Bukhsh AR: Anti-lung cancer potential of pure esteric-glycoside condurangogenin A against nonsmall-cell lung cancer cells in vitro via $\mathrm{p} 21 / \mathrm{p} 53$ mediated cell cycle modulation and DNA damage-induced apoptosis. Pharmacogn Mag 11 (Suppl 1): S73-S85, 2015.

38. Nie C, Luo Y, Zhao X, Luo N, Tong A, Liu X, Yuan Z, Wang C and Wei Y: Caspase-9 mediates puma activation in UCN-01-induced apoptosis. Cell Death Dis 5: e1495, 2014.

39. Brentnall M, Rodriguez-Menocal L, De Guevara RL, Cepero E and Boise LH: Caspase-9, caspase-3 and caspase-7 have distinct roles during intrinsic apoptosis. BMC Cell Biol 14: 32, 2013.

40. Strappazzon F, Torch S, Chatellard-Causse C, Petiot A, Thibert C, Blot B, Verna JM and Sadoul R: Alix is involved in caspase 9 activation during calcium-induced apoptosis. Biochem Biophys Res Commun 397: 64-69, 2010.

41. Li W, Qiu X, Jiang H, Han Y, Wei D and Liu J: Downregulation of miR-181a protects mice from LPS-induced acute lung injury by targeting Bcl-2. Biomed Pharmacother 84: 1375-1382, 2016.

42. Thangarajan S, Ramachandran S and Krishnamurthy P: Chrysin exerts neuroprotective effects against 3-Nitropropionic acid induced behavioral despair-Mitochondrial dysfunction and striatal apoptosis via upregulating Bcl-2 gene and downregulating Bax-Bad genes in male wistar rats. Biomed Pharmacother 84: 514-525, 2016

43. Chen XF and Liu Y: MicroRNA-744 inhibited cervical cancer growth and progression through apoptosis induction by regulating Bcl-2. Biomed Pharmacother 81: 379-387, 2016.

44. Feng W, Cai D, Zhang B, Lou G and Zou X: Combination of HDAC inhibitor TSA and silibinin induces cell cycle arrest and apoptosis by targeting survivin and cyclinB1/Cdk1 in pancreatic cancer cells. Biomed Pharmacother 74: 257-264, 2015.

45. Wu R, Tang S, Wang M, Xu X, Yao C and Wang S: MicroRNA-497 induces apoptosis and suppresses proliferation via the Bcl-2/Bax-caspase9-caspase 3 pathway and cyclin D2 protein in HUVECs. PLoS One 11: e0167052, 2016.

46. Wang C, Yao B, Xu M and Zheng X: RIP1 upregulation promoted tumor progression by activating $\mathrm{AKT} / \mathrm{Bcl}-2 / \mathrm{BAX}$ signaling and predicted poor postsurgical prognosis in HCC. Tumour Biol 37: $15305-15313,2016$.

47. Mattheolabakis G, Ling D, Ahmad G and Amiji M: Enhanced anti-tumor efficacy of lipid-modified platinum derivatives in combination with survivin silencing siRNA in resistant non-small cell lung cancer. Pharm Res 33: 2943-2953, 2016.

48. Cheetham AG, Keith D, Zhang P, Lin R, Su H and Cui H: Targeting tumors with small molecule peptides. Curr Cancer Drug Targets 16: 489-508, 2016.

49. Rhodes A and Hillen T: Mathematical modeling of the role of survivin on dedifferentiation and radioresistance in cancer. Bull Math Biol 78: 1162-1188, 2016.

50. Cui X, Shen D, Kong C, Zhang Z, Zeng Y, Lin X and Liu X: $\mathrm{NF}-\kappa \mathrm{B}$ suppresses apoptosis and promotes bladder cancer cell proliferation by upregulating survivin expression in vitro and in vivo. Sci Rep 7: 40723, 2017.

51. Shintani M, Tashiro A, Sangawa A, Yamao N and Kamoshida S: Expression of chromosomal regional maintenance protein-1 may be associated with subcellular survivin expression in human gastric and colorectal carcinoma. Oncol Lett 12: 4630-4634, 2016.

52. Tamm I, Wang Y, Sausville E, Scudiero DA, Vigna N, Oltersdorf T and Reed JC: IAP-family protein survivin inhibits caspase activity and apoptosis induced by Fas (CD95), Bax, caspases and anticancer drugs. Cancer Res 58: 5315-5320, 1998. 